\title{
BUREAUCRATIC REFORM IN JAKARTA: JOKOWI LEADERSHIP STYLE
}

\author{
Jerry Indrawan \\ International Relation Department \\ Paramadina University \\ jerryindrawan@yahoo.com
}

\begin{abstract}
Jakarta is still facing many problems regarding bureaucratic system. It positions as the state capital does not guarantee that bureaucratic reform has already establish in perfect manner. At least there are three problems that need to be reformed. First, corruption in three fields: administrative services, practices of construction projects, and law enforcement. Second, institutional inefficiency. The local government bureaucratic structure is too fat, because of too many departments and sections exist, and resulting in the amount of local budget use to cover it. Third, corruptive mentality from most of the civil servants, resulting in deficient public services. Joko Widodo, better known as Jokowi is a new Governor of Jakarta. Before, he was a Mayor in Solo, Central Java for seven years. He brought bureaucratic reform to that city, that leads him in winning various national, even international achievements, such as the World Third Best Mayor from The City Mayor Foundation. Jokowi success is mostly because of his leadership ability. His leadership style is also different than others. There is no gap between him and his people. There is no strict protocol either that restrain him in meeting his people anytime he likes. He ignored bureaucratic formality, because such will dissociate him with his people. One of his well known method is "blusukan", which means "entering a place where nobody wants to" in Javanese. He applied "blusukan" as a way in knowing what people wants by visiting them, even to a slum area where no public officials even care to think. In doing this, he can see the real problem in the society and starts to reform the government based in his field observation. He minimized the long arm of bureaucracy, in terms of efficiency and knowing what's best for his people. He even said that he will only spend one hour every day in the office, and the rest include saturday and sunday) will be spent in the field. He thinks that the only way we know the problem lies on this city is experience it, and the experience will not be experienced by staying in the office. He has to be with his people, so that he can find a solution for them. This paper will see Jokowi leadership style in leading Jakarta and the influence it makes to reform Jakarta's local government bureaucratic system. Does Jokowi leadership style will be the perfect answer to the city real problems nowadays? Conducted research methodology was qualitative, through library research. The primary data will be collected from interviews with related informants. The informants will be purposively determined to sharpen the information gathered. Last, the secondary data will be aquired from books, journals, internet, newspapers, etc.
\end{abstract}

Keywords: Bureaucratic Reform, Leadership Style, "Blusukan" 


\section{A. Introduction}

Joko "Jokowi" Widodo and Basuki "Ahok" Tjahaja Purnama have officially assumed office as Governor of Jakarta and deputy governor respectively for the next five years (2012-2017). Through a dynamic election, the majority of Jakartans showed they craved change. The success story of Jokowi-Ahok, with their young, visionary, and low-profile images, signifies the momentum for the rise of increasing democratic life in Indonesia, particularly in local level. Before taking office in the capital, Jokowi was a Mayor in Solo, Central Java for seven years. He brought bureaucratic reform to that city, and leads him in winning various national, even international achievements, such as the World Third Best Mayor from The City Mayor Foundation. ${ }^{1}$

Jokowi was born in Surakarta on 21 June 1961. His father was a jobbing carpenter living in poor housing on the river bank. He graduated in Engineering and Forestry from Gadjah Mada University in Yogyakarta on 1985. Jokowi's business career began in the mid 1980's. He founded a furniture importing and exporting company which had its ups and downs, but was successful overall and made him financially independent. He ran the business for 19 years. He became prominent and influential within the business community in his home town, Solo.

During his two terms as Mayor of Solo, he and his deputy won $91 \%$ of the vote in 2010 (his second term). Jokowi

\footnotetext{
${ }^{1}$ Bangkok Post, January 8, 2013. Jokowi "Third Best Mayor in the World". Accessed from http://www.bangkokpost.com/breakingnews/32982 2/jakarta-governor-third-best-mayor-in-world on August 17, 2013.
}

applied reforms to the structures and cultures of the city administration, which reflected his business experiences dealing with it and his understanding of public concerns. Many services were clustered into one-stop shops as has been introduced in other cities in Asia and Europe.

During his time as a businessman, also tried to improve service quality and public respect by sending managers and other staff on re-training courses designed to make them more responsive to people's needs. Nevertheless, I think he can be ruthless too in eliminating petty corruption. One thing fascinating about him, his wealth accumulated through business has allowed Jokowi to decline to draw his salary as a politician. This has boosted his popularity as has his decision to decline to take up entitlements to new official cars. He hopes this sends a good message to his bureaucratic staffs.

Bureaucratic reform in Jakarta is a must. In order to be the front line of Indonesia's global development, Jakarta must change to improve. Jokowi's success in last year election brought hope that improvement will take place, especially after seeing what he can do in Solo. So, does Jokowi leadership style will be the perfect answer to the city problems? We will see that his leadership style in leading Jakarta and the influence it makes to reform Jakarta's local government bureaucratic system is a very interesting phenomenon to observe.

\section{B. Leadership and Bureaucracy}

Leadership really does matter in shaping the character and quality of public services and government institutions. Leaders give meaning to the people within 
the organizations they lead, and are role models for coping with particular circumstances and creating a dynamic environment. Unfortunately, although policymakers speak of its importance, leadership discourse and development is eclipsed by political and legal hysteria in Indonesia. Key policy and decision makers in this country still maintain that leadership about power, formal or legal authority, status, and position.

Leadership is about making a difference, spreading influence through inspiration, having and sharing visions, promoting goals and values that shape character as well as spirit, and about learning and growing in sustainable ways. Neither the public nor government officials seem to embrace such meaning. Government officials need strategic minds to respond to vigorous change in their environment. In many cases they are simply unready, unwilling or incapable. The paradigm, in place for decades, is absolute compliance to regulations, decrees and bureaucratic procedures that they themselves have set up. The bureaucratic system in the country has directly or indirectly built a comfort zone for their working style.

Meanwhile, the understanding of public administration within the meaning of bureaucracy has become a traditional view of understanding public administration. Bureaucracy only meant as a civil servant. The study of bureaucracy is not only focused on the behavior, but rather to a formal order, considering the direction of the studies is to understand bureaucratic formal structure rather than bureaucratic behavior. Bureaucracy is a very strong institution with the ability to increase the potential capacities towards good or bad things in its existence as a neutral instrument of rational administration on a large scale. In modern society, where there are so many routine and regular administrative businesses, bureaucracy in practice is described as civil servants. $^{2}$

Leaders role in public policy are vital, so it can be said that without a leader, and good leadership, public policy will be in vain. Constellation of leadership in public policy can be described as follows: ${ }^{3}$

\footnotetext{
${ }^{2}$ Riant Nugroho. 2011. Public Policy. Jakarta: Elex Media Komputindo. P.132-3.

${ }^{3}$ Ibid., P. 257.
} 


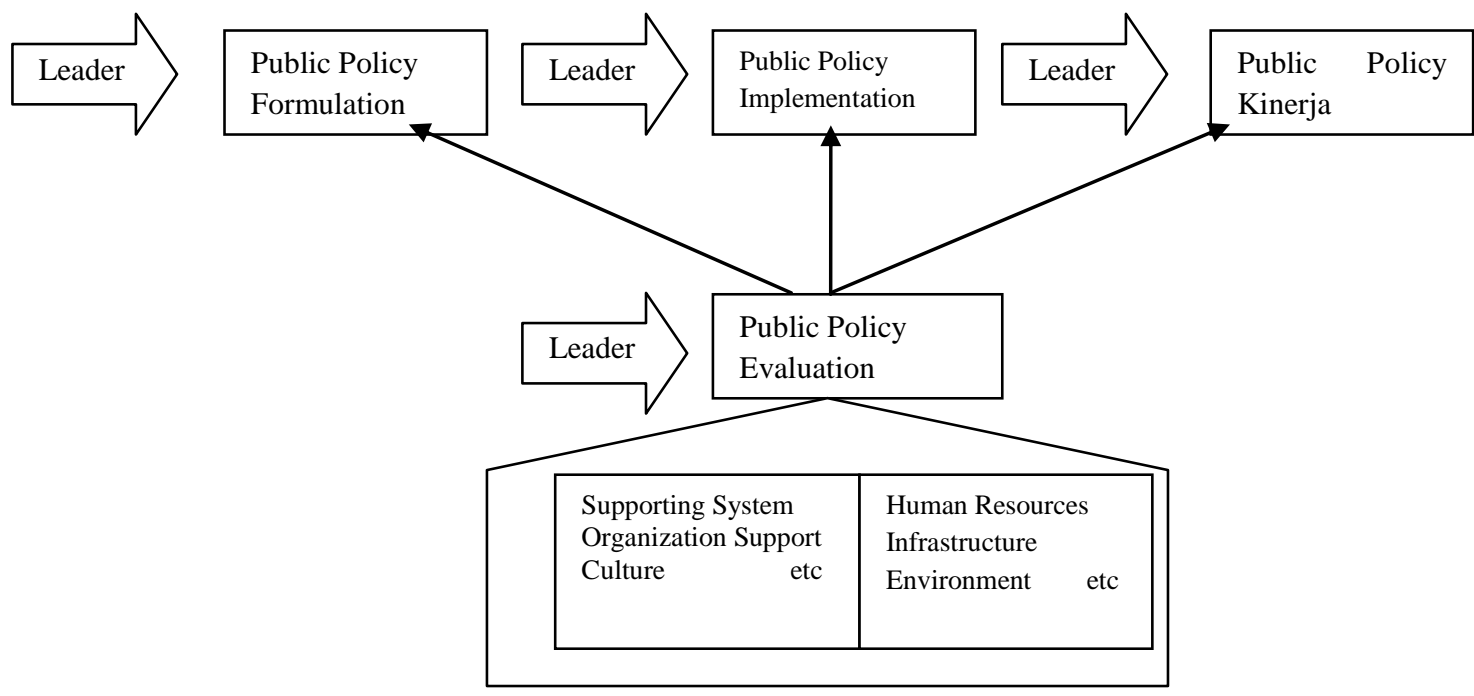

What is interesting about Jokowi's leadership? Can we learn anything about changing the organizational environment and leadership approach from him that can be applied to Jakarta's bureaucratic system? For example, when Jokowi talks to mayors, district heads and sub-district leaders about the need for them to engage with their environment, he actually speaks about the urgency and importance of transformation in leadership culture. $\mathrm{He}$ is talking about a change from power orientation to service orientation, from dictatorship to democracy. The problems facing Jakarta are complex. They require engaging leaders. Engaging leaders probe situations in responsive and effective ways.

Speaking on this matter, political leadership supposed to have stronger control on bureaucracy. Why? In Indonesia, every local official leaders, mention governor, reagent, and mayor, were elected in democratic ways. The local election that held every five years, like the general election, is the only channel a citizen could run for those positions, with one man one vote system. So, the political legitimacy of an elected public official is high, compare than the bureaucratic system itself.

That is why with stronger legitimacy, the well known corrupt bureaucratic system in Indonesia, suppose to be easily eradicated by elected public officials. Unfortunately, this doesn't go that way. A long lasting tradition of ineffective and corrupt Indonesian bureaucratic system infected the newly elected leader. Instead of eliminating such culture, it preserved automatically. This condition can't be allowed to happen much longer. Power culture syndrome should be turned into a service delivery culture. George Frederickson added, that new public administration seeks not only to carry out legislative mandates as efficiency and economically possible, but to both influence and execute policies which more 
generally improve the quality of life for all. $^{4}$

In a growing democratic country, this is a major problem for Indonesia, especially in happens in almost every level. The spirit of democracy should bring effectiveness in bureaucracy, instead of ineffectiveness of public service. Moreover, legitimize leaders mostly does not take effective action to deal with long arm bureaucratic system. They are lulled comfortably with Indonesian bureaucracy, because in some way it benefits them. Few leaders take this matter in their own hand, Jokowi is one of them, and become the most effective one.

We can call Jokowi leadership as a soft democracy style. We named it that way because Jokowi use non-violence approaches and he put forward dialogue as a problem solver rather than coercive style of leadership. This is a kind of approach suitable for policies related to public interests. For example, regulating sidewalk vendors. Previous governor mostly use violence in regulating the sidewalk vendors, sometime harsh treatment and contumely to them. In other hand, Jokowi use solutive and persuasive methods with win-win solution agreement for both sides.

A very difficult task in short time to remodel and reorganize Jakarta provincial government bureaucratic system, especially with a system that has been running for so long, and of course, resistant to changes. Jokowi leadership style, in the other hand, is quite different than other leadership styles that practiced most in Indonesia. His leadership has the

\footnotetext{
4 George Frederickson. Toward a New Public Administration, in Frank Marini (ed). 1971. Toward a New Public Administration. Scranton: PA. Chandler. P. 314.
}

ability to get him closer to the people, instead of making gaps. He disregarded strict protocol and ignored bureaucratic formality, because such will dissociate him with his people. Therefore, it is very interesting to examine what kind of leadership approach done by Jokowi to reform Jakarta Bureaucratic system.

\section{Jokowi's Leadership Style}

Jokowi is well known for his reputation, in terms of leadership, since he was still a mayor in Solo. In my view, there are several leadership qualities performed by Jokowi. These leadership qualities come from his ordinary life, without affectation. And this leadership qualities will bring changes to Jakarta bureaucratic system, because is already caught the eyes and attract people hearts. Here are several of those leadership qualities.

To start a leadership from small things, what we can do first, is a beginning of the ability to do what you could not do. To fix Jakarta bureaucracy that has lasted so long is definitely not easy. I am very sure Jokowi understand this problem, and also all the challenges and difficulties. Starts from going to communities and have a dialogue with them about their daily lives, shows an attempt to do the small things first before completing the main issue. In this way, he can outsmart the provincial government bureaucratic system, and then formulate best steps to respond with people problems through non-bureaucratic channels. He realize that the people of Jakarta is the main stake holder of his government, for that he wants to started in understanding what are the problems the people's facing. 
I look at this Jokowi's strategy in a very positive and promising way. If Jokowi can solve the problems exist in the society, I believe the people will support himself in facing Jakarta's Provincial Government feudalistic bureaucracy. So far, if there is newly elected local leaders want to reform their bureaucratic government, they always impeded either by systems or by old timers in the provincial government, who do not want their comfort zone to be disturbed. If able to gain public sympathy, Jokowi will certainly acquire large political supports. Bureaucratic reform efforts can work well if the leader is able to make removal steps to clear those old timer and fix the system, then replace with new bureaucratic patterns that focus on optimal service for the society. This all started by doing small things first.

Jokowi is an example of innovative leader. The traits of innovative leaders are idealist, yet pragmatists with welldeveloped inner compasses to keep them grounded. They are committed to creating a better world for the people. Leaders of innovation have the talent of soloist and the temperament of orchestra players. These leaders are perfectly capable of leading from the front. In addition, leaders of innovation are systems thinkers with an action oriented. They enjoy unraveling complex technical and organizational issues down to their core. It is no surprise that they serve as role models for others. ${ }^{5}$ During an interview with the author, Jokowi said that he already master the

\footnotetext{
${ }^{5}$ Linda Hill, et all. Unlocking the Slices of Genius in Your Organization: Leading for Innovation, in Nitin Nohria and Rakesh Khurana (ed). 2010. Handbook of Leadership Theory and Practice: A Harvard Business School Centennial Colloquium. Boston: Harvard Business Press. P. 626-637.
}

problems. Afterwards, he discussed with the rest of his provincial government staffs to formulate the best solution for it. $\mathrm{He}$ does all decision making, and usually Vice Governor Ahok is the driving force, in terms of the implementation. ${ }^{6}$

According to John W. Gardner, the most versatile leadership instrument is communication. The cause of the rise and fall of leadership is communication, Therefore communication should not be top-down or dictator styled, moreover done in one way direction. Leader must have a forward-thinking minded in making decision, always move forward, and become a good navigator. A good navigator will collect as many information from various sources. He knows that he do not posses all answers required, therefore he listens and encourage the participation of those he leads. ${ }^{7}$ Jokowi purpose in doing "blusukan" is to know what the real problem in the field. Thus, he can arrange proper planning to find ideal solutions. The Jakarta Provincial Government then can make it real with their policy making procedure. ${ }^{8}$

This is the essence of "blusukan". 9 Jokowi entered places where other leaders reluctant to go in order to collect information and hear the aspirations of his people, or at least talk with them. This is a form of citizen engagement, where he

\footnotetext{
${ }^{6}$ Joko Widodo, interview with author, August 21, 2013.

7 John C. Maxwell. 2011. The Maxwell Daily Reader. Jakarta: Bhuana Ilmu Populer. P. 4.

${ }^{8}$ Joko Widodo, interview with author, August 21, 2013.

${ }^{9}$ Blusukan means entering a place where nobody wants to (Javanese). Jokowi applied "blusukan" as a way in knowing what people wants by visiting them, even to a slum area where no public officials even care to think. In doing this, he can see the real problem in the society and starts to reform the government based in his field observation.
} 
involve the people of Jakarta to also contribute to his policy making process. When the people feel that they are being part of a policy making process, they will embrace and respect the leader, and resulting to a form of enormous loyalty to Jokowi. Jakarta needs leader who see their principal role as creating a world or work environment in which others can share their diverse talents and realize their potential for their community. ${ }^{10}$ People will follow a person who inspires them. A person with vision and passion can achieve great things. The way to get things done is by injecting enthusiasm and energy. Jokowi makes it clear that in Indonesia, leading by example is very important. If the leader set a good example, his people with follow him, even emulate him. ${ }^{11}$

Jokowi also has an ability to impress people. One of them, of course, because of he asked them to participate. Jokowi does not require, so called, political imaging, but by his action (especially his "blusukan" method) positive image continues over him. Many leaders think that if they can impress people, they can also influence them. This could be a problem, because if impressing people is our goal, we will exaggerate and then looks arrogant. Finally, there will be gap between leaders with their own people. Leaders will no longer earn trust from the people to be their representatives in the government. If the people do not trust their leaders, how can the bureaucratic system and the civil servant working inside also be trusted.

Jokowi can attract other people to come because he has great charisma. He

\footnotetext{
${ }^{10}$ Hill. Op cit., P. 635.

${ }^{11}$ Joko Widodo, interview with author, August 21, 2013.
}

focuses on other, not himself. $\mathrm{He}$ communicates with his people because he believes that they have value. He asked question about others, he listens, he try not to be the center of attention, and never pretend to be perfect. His publicity arises because of his performance and trust comes because he hears other. He makes others to be his public relations simply because of what he achieved. There is a saying: "People who gossip is one who talks to you about others, annoying people is one who talks to you about himself, and a brilliant conversationalist is one who talks to you about yourself". ${ }^{12}$

Many leaders also often make a common mistake in trying to lead others before having a good relationship with them, especially political leaders. Although, must be difficult for political leaders to know everyone, but it is not an excuse for not trying. The "blusukan" method is one of Jokowi's methods in knowing his people. By come directly to them, fresh information will then be collected, without having to pass through long arm of bureaucratic system. Former Indonesian President Megawati Soekarnoputri, when being asked about the performance of Jokowi, she sees that he has good performance and he is qualified as a leader. The condition of capital city is increasingly chaotic, thus the city needs honest, hardworking, and caring figure, which is also has a willingness to help the poor. These criteria, is built on Jokowi's leadership. $^{13}$

Many cases happen in Indonesia regarding to local election that elected

\footnotetext{
${ }^{12}$ Ibid., P. 37.

${ }^{13}$ Bisnis English, April 15, 2013. Jokowi Become too Skinny in Six Months. Accessed from http://en.bisnis.com/articles/jokowi-become-tooskinny-in-six-months on August 15, 2013.
} 
leaders are so action-oriented and agenda driven, so, that they do not give priority to the human aspects (their people). As already said above, it is very difficult to solve problems in Jakarta, therefore, it require an extraordinary efforts. Jokowi started by focusing on the human aspect first. Direct communication with the people, done not only during campaign time, but soon after elected, has become Jokowi key success of his bureaucratic reform. It is very natural if people want to get close to a leader that give much attention and care for them. They will speak highly of him.

Other than that, Jokowi commitment for his duty and position should be appreciated. Commitment is very important because most leaders (political) only concerned with their own personal interest and forget about the people's interest. Effective leader is one who always kept his commitment. The right commitment will inspire and attract many people. Such commitment showed that Jokowi has confidence as a leader. People will believe and sure of him. People will accept the figure (person) first, then their vision. Sitting all day in the office is not a proper commitment to lead, but put aside some time to communicate with the people is an effective way to reform Jakarta's bureaucratic system.

Jokowi's "blusukan" is the vital ingredient in all this. Besides going directly to his people, by constantly hitting the ground and conducting sudden checks on his own civil servants, he won the trust of Jakartans. And this trust is like social capital. Moreover, in communities where politicians are viewed with scepticism if not disdain, it means that people are more inclined to believe Jokowi. He is now drawing on this social capital in order to push through other programs that benefit Jakartans, tackling flooding, poverty, health and education, traffic congestion, and of course, bureaucratic reform. "Blusukan" (which Jokowi undertakes without scores of political aides and security officials) also ensures leaders stay in touch with the problems on the ground and truly understand what is going on.

Transformational leaders are always visible and will stand up to be counted rather than hide behind their troops. They show by their attitudes and actions how everyone else should behave. They also make continued efforts to motivate and rally their followers, constantly doing the rounds, listening, soothing and enthusing. Transformational leader has to be very careful in creating trust, and their personal integrity is a critical part of the package that they are selling. In effect, they are selling themselves as well as the vision. Overall, they balance their attention between action that creates progress and the mental state of their followers. Perhaps more than other approaches, they are people-oriented and believe that success comes first and last through deep and sustained commitment. ${ }^{14}$ In my perspective, Jokowi is one of such leaders.

He is a type of leader that will give more attention and concern to ideas, because they always look for it. Of course, if we to find good ideas, we have to find it. Good ideas are very rare to come after you. We have to give our full efforts to discover brand new and quality ideas.

\footnotetext{
14 More about transformational leadership, see Bernard M. Bass. 1990. From transactional to transformational leadership: Learning to share the vision. New York: Free Press. P. 19-31.
} 
"Blusukan" is also one of Jokowi efforts to look for ideas. Sometimes, bright ideas can't be found in ordinary or normal places, but slum areas, riverbanks, settlements under the bridge, and other places no leaders, even public officials care to think. Such unlikely places offers ton of ideas to fix Jakarta. Things like this make Jokowi leadership style considered out of ordinary.

\section{Problems in Jakarta}

Jakarta is a metropolitan city, behind all its glory save a lot of trouble. A city that has a budget of over 40 trillion RP (4.3 billion US\$) a year and accounts for over $16 \%$ of Indonesia's economic activity. There are at least five problems facing Jakarta, namely poverty, social inequality, traffic congestion, garbage, and flood. As a big city like Jakarta should be able to provide at least seven basic facilities, such as housing, clean water, transportation, security, infrastructure, health, and education. The problem is, all of the above cannot be enjoyed equally.

$$
\text { I feel Jakarta Provincial }
$$

Government has not been able to provide effective service for citizens. Jakarta bureaucracy is too inward looking, incompetence, inconsistence, and impotence. Diseases such as these will enrich corruptive working nature in Jakarta bureaucratic system. Rather than solving the problem, instead it will add more problems. Every year, these accumulating problems going further away from proper solutions. The main task of a leader is to solve such problems, because this is the real problem faced by people in Jakarta. Without proper solutions and brave efforts from Jakarta leader, it could be even harder to solve in the future.
Bureaucratic reform in Jakarta should start by solving all of this problems. Bureaucratic reform should not be focused only on bureaucratic system, but also how to look beyond the problems, that exist in society. Jokowi aware of this, that's why he did the "blusukan". He is looking for the root of the problems in Jakarta, not from his staff daily reports in office, but by going directly to the people to find out. By looking at the root of the problems, then the effectiveness of the bureaucracy itself will run well. Like already mentioned above, Jokowi purpose in doing "blusukan" is to know the real problem in the field. Thus, he can arrange proper planning to find ideal solutions. The Jakarta Provincial Government then can make it real with their policy making procedure. $^{15}$

Bureaucracy is actually a system that serves the needs of the people (community), hence convenience of the service is the main focus, not just a routine intricate administrative duties. In the middle of Jakarta's bureaucracy that does not run properly, Jokowi make a breakthrough by doing a new style bureaucracy. He turns royally bureaucratic paradigm into service bureaucracy. He visited his people to know what they need. From his "blusukan", he gets a lot of input that were not delivered by his bureaucratic staffs. This inputs will be use to reform Jakarta Provincial government bureaucracy.

Public sector management can no longer use the static and linear method. Facing various bottlenecks and complex issues of development, the bureaucracy should be able to change in response to the

\footnotetext{
${ }^{15}$ Joko Widodo, interview with author, August 21, 2013.
} 
dynamics of the external environment. A variety of innovations and breakthroughs must be injected into the body of the bureaucracy. Commitment of the top political leaders to reform is important because true bureaucratic reform is a political process.

Jokowi way of working is very interesting to me because bureaucratic reform generally starts from fixing the structure and system, but Jokowi reverse the steps. Persuasive approach to the people comes first, thus the problems that appear will be delivered properly, through a formal channel of a bureaucrat (which is Jokowi as a governor), but did it informally and very effective. For that, let us discuss some of the problems in Jakarta, and what actions have been carried out by Governor Jokowi to fix it.

First, flooding problem. Flooding cause losses of billions of dollars because it's occurred every year, almost like an annual ritual in Jakarta. Direct casualties or due to diseases outbreak is also inevitable. According to Bappenas, losses due to flooding in Jakarta and surrounding areas (Bogor, Bekasi, Tangerang, Depok) reached more than Rp. 5.2 trillion. Loss was due to inundation of tens of thousands of homes, some even destroyed or swept away. Data from Evironmental NGO in Jakarta (Walhi) and Jakarta Agency of Environmental Control Impact (BAPEDAL) shows that Jakarta citizens bear the losses caused by flooding of $\mathrm{Rp}$. 95 billion per day. This number is much larger than the budget for flood prevention by Jakarta Provincial Government, which is only Rp. 500 billion per year. ${ }^{16}$

\footnotetext{
${ }^{16}$ Budiman Tanuredjo (ed). 2007. Jakarta Memilih: Pilkada dan Pembelajaran Demokrasi. Jakarta: Penerbit Buku Kompas. P. 10.
}

Actually, flooding is one of the most complex problems in Jakarta, because it involves other external parties. Jokowi said that flooding in Jakarta is rather difficult to overcome in quick manner. Many stakeholder needs to be firm in dealing with this problem. For example, the river management from upstream to downstream. In upstream, the West Java and Banten Provincial Government should also care for this. Jakarta only dealing with small rivers and canals in the downstream. The big ones should be taken care by the central government, via the Ministry of Public Work, and with the help from three provincial governments (Banten, West Java, and Jakarta). Although, he admits that such synergy might be difficult to carry out. ${ }^{17}$

To handle this problem, Jokowi has several ideas, some of them already successful. For instance, he has persuaded squatters in Pluit, North Jakarta, to move, freeing up space to boost the city's flood prevention programs. This too was a Herculean effort, involving the relocation of some 7.000 families, and the Governor was able to win their consent with a combination of gentle persuasion, humility and determination. Besides that, cause of flooding could be as many lands in and around Jakarta bought by developers to build housing complex. Jokowi reverse that fact. Now, the city will buy back these lands and we will build green spaces and reservoirs. Lands already and will be purchased, like 28 hectare in Pulo Mas area, 30 hectare in BMW Park, and 18 hectare in Daan Mogot streets. Jokowi also

\footnotetext{
${ }^{17}$ Joko Widodo, interview with author, August 21, 2013.
} 
will conduct an audit to some buildings in Jakarta and observe their building permit. ${ }^{18}$

Jokowi formulates flood prevention programs to overcome flooding. His first plan is to relocate riverbank squatters and widen rivers to restore high water flow rates. The Ciliwung, Pesanggrahan, Sunter and Angke rivers, which are now currently only 15 meters, will be widened to 50 up to 60 meters. He added that the city administration had allocated Rp. 250 billion (\$26 million) from the city budget this year for normalizing the flow of the Ciliwung River, and another Rp. 400 billion for the Pesanggrahan River.

Next program involved building a spillway linking the Ciliwung to the East Flood Canal. A major factor for the flooding in Central Jakarta, which brought traffic and business activities in the city to a halt few months ago, was a breach in the West Flood Canal through which a branch of the Ciliwung flows. Other programs that the city administration is pursuing is the building of reservoirs in the upstream areas of Ciawi, in Bogor, and Cimanggis, in Depok, as well as a pump system in North Jakarta to more adequately deal with large amounts of flood and rainwater runoff. Jokowi also proposed a system of around 10.000 wells, ranging in depth from four to 200 meters, to be built throughout the city to help absorb high amounts of runoff and improve the quality of groundwater. A final program involves building a highcapacity multipurpose tunnel running

18 MPR RI, January 21, 2013. Jokowi: Enam Langkah Mengatasi Banjir Jakarta. Accessed from http://www.mpr.go.id/berita/read/2013/01/21/1154 1/jokowi-enam-langkah-mengatasi-banjir-jakarta on August 15, 2013. across much of the length of the city to channel floodwater directly out to sea. ${ }^{19}$

Second, poverty problem. Poverty can be defined as a lack of access to vital things in life. In jakarta, there no accurate data on the amount of income Jakartan has. Although, Paul McCarthy from World Bank in Global Report (2003), citing from a survey institute, in six major cities in Indonesia, $22 \%$ of the urban population lives on less than Rp. 350.000 per month. About 20\% live around Rp. 350.000 to Rp. 500.000. The World Bank noted, about $50 \%$ of households in Indonesia is vulnerable to poverty. ${ }^{20}$ Jakarta province is the richest province and in top of the list of Human Development Index provinces in Indonesia (0.770) in 2009. Poverty headcount ratio at national poverty line in Indonesia is $12 \%$ of population (2012). ${ }^{21}$ That is around 28 million people. In 2013, the number of poor people, which is the population with per capita expenditure per month is below poverty line (spending less than Rp. 355.480 per month) in DKI Jakarta reach 354 thousand people $(3.55 \%){ }^{22}$

Jokowi has described social disparity as his biggest worry. Jokowi's healthcare and education programs have been given top priority by him, who shows

\footnotetext{
${ }^{19}$ Jakarta Globe, January 21, 2013. SBY Approves Jokowi's Flood Prevention Programs. Accessed from http://www.thejakartaglobe.com/archive/sbyapproves-jokowis-flood-prevention-programs/ on August 09, 2013.

20 Martina Hartiningsih. Hak Warganegara vs "Kedermawanan". Kompas, Tuesday, July 10, 2007.

21 The World Bank. Indonesia. Accessed from http://data.worldbank.org/country/indonesia on 16 August, 2013.

22 Statistics Official Publication. Jakarta Province Poverty Level in March 2013. Statistics Central Body (BPS) Jakarta Provincial Government, no. 32/07/31/XV, July 1, 2013. P. 1.
} 
a concern for poverty unmatched by both his predecessors and by the national government. Although, there can be no question that Jakarta and its 360 slum areas have been severely neglected for all this years. Inaction on this issue is morally inadmissible, and Jokowi represents a break with the past in a country that has largely ignored its poorest citizens since the days of the New Order regime.

Third, traffic problem. Every day, more motorcycles and cars running around in Jakarta streets, causing heavy traffic in almost every parts of the city. Jokowi maintain his predecessor policy to use busway program to ease traffic jam in Jakarta. Three more busway corridors are planned for the city and these corridors will be elevated in an attempt to alleviate congestion (as opposed to actually exacerbating congestion as the current busway lanes arguably do). The capital's MRT project is under way and will finally steam out of platform one. Even though, this MRT scheme is definitely going to need some heavy backing from the central government. The city budget is hoping to provide around $60 \%$ of the funding needed for the project with the government providing the rest of the money in order to repay a loan from the Japan International Cooperation Agency.

Jokowi also announced his initial approval in January 2013 for a plan to build several new elevated roads across the city. These will be toll roads and financed by borrowing against the future income stream. He says he has approved the extra road space for vehicles because Jakarta needs to supplement investment in a metro system and other public transport with more road connectivity if it is to transform into a modern city. The proposed scheme would be constructed from 2014 and carries an estimated price tag of Rp. 42 trillion for the $67 \mathrm{kms}$ of routes. In late January 2013, Widodo and central government were edging towards an agreement on a $49 / 51 \%$ split of the cost of the first phase, which is priced at Rp. 16 trillion.

Related to traffic issue, street vendors also causing heavy traffic in Jakarta. Therefore, restructuring of sidewalk vendors has become one of Jokowi's agenda. One of the place well known of its traffic due to this matter is Tanah Abang Market. Tanah Abang market (a popular destination for Indonesian shoppers) is a vast commercial hub whose tentacles reach deep into virtually every hamlet all over the nation. Famed for its textiles, the market has been in existence for well over 250 years. With an estimated 28.000 merchants plying their wares and spread over six floors, including a 2.000 person capacity mosque, Tanah Abang is one of Asia's busiest trading centers.

Tanah Abang with all its traders mutates into a Bermuda Triangle of sorts, snarling traffic for miles all around, including the all-important $\mathrm{KH}$ Mas Mansyur street, one of the capital's main north-south arteries. The 700 street vendors outside the main structure are the main source of the congestion. But persuading them to relocate requires tact and perseverance. Besides the vendors, there is an entire infrastructure of vested interests from the local gangs (known as "preman") to various businesses and the authorities themselves.

Jokowi faced a similar challenge during his earlier tenure as Mayor of Solo, Central Java. Back in December 2005, he 
had convinced a group of street vendors in Solo's Banjarsari Park to relocate to a new market in Kithilan Semanggi. Jokowi did a successful Societies program by holding more than 50 lunch meetings with the vendors. The meetings were not one-sided. $\mathrm{He}$ listened as much as he talked, pondering over their demands and collecting data as he worked towards a consensus.

This degree of inclusiveness is exhausting and not for the faint-hearted. However, the interventionist style has formed the basis for his leadership of Jakarta. In order to resolve the knotty issue of Tanah Abang, he once again hit the ground to listen to the people. The going has not been easy, Jokowi and his deputy Basuki Tjahaja Purnama (Ahok) have been criticized by everyone from local politicians and national leaders to NGOs which have accused them of not understanding the needs of the street vendors. However, patience appears to be paying off. Tanah Abang's street vendors have finally agreed to move to a nearby alternative location, called Block $\mathrm{G}$, where some 1.000 kiosks have been set up, rents will only be charged after six months.

Fourth, health and education problems. One of Jokowi's main campaign programs when he was running for governor was to improve education and health sectors in Jakarta. He has launched several pro-poor initiatives, including Jakarta Health Card (Kartu Jakarta Sehat) and Jakarta Smart Card (Kartu Jakarta Pintar) programs to support citizens and students from low-income families. Jakarta Health Card program was set up by Jokowi upon taking office. It will allow all Jakarta residents to access free medical services at the city's community health centers and hospitals. The program aims to cover all Jakarta citizens, but Jokowi, said the poor were the priority. ${ }^{23}$

On the initial stage, as much as 3.000 Jakarta Health Cards were distributed to the residents who live in East Pademangan Urban Village (North Jakarta) and Tambora Urban Village (West Jakarta). Gradually, there will be 4.5 million Jakarta Health Cards distributed to Jakarta citizens. Besides lower income people, the card will also be distributed to the haves if they are willing to be treated in class III room. Last May, Jokowi distribute 1.7 million new Jakarta Health Cards. Before this, nearly 500.000 cards have been distributed since its initial launched last year. Jakarta Health Card has an electronic chip that will be able to keep medical records of the owner, making it easier for hospital and Puskesmas to track the patient's history. It will also make administrative matters easier. As a result, every Puskesmas in Indonesia will be given a scanner. ${ }^{24}$

Jakarta Health Cards covers various types of treatment, including chemotherapy for cancer patients, as long as the patients are willing to be hospitalized in the third-class rooms. In the events of emergency and unavailability of third-class rooms, however, patients may be allowed to stay in second-class rooms, subject to approval of Jakarta's healthcare

\footnotetext{
23 The Jakarta Post, November 10, 2012. Jokowi Set to Launch Jakarta Health Card. Accessed from http://www.thejakartapost.com/news/2012/11/10/jo kowi-set-launch-jakarta-health-card.html on July 30, 2013.

24 Tempo English, May 28, 2013. Jokowi Distributes the New, Improved Jakarta Health Card Today. Accessed from http://en.tempo.co/read/news/2013/05/28/05748378 7/Jokowi-Distributes-the-New-Improved-JakartaHealth-Cards-Today on August 14, 2013.
} 
agency (Dinas Kesehatan DKI Jakarta). Jakarta Health Cards records the medication history of every patient and has a proper billing system. The reception just needs to swipe the card and fill in the data into the system. The local health center or recommended hospitals will then claim the medication cost to the government. Better record helps doctors to understand the patients and take appropriate measures, resulting in more effective medication.

The Jakarta Smart Card launched by Jokowi last December. The purpose was also for low income families to get access to better education. In first phase, Jokowi distributed 3.013 Cards for 1.662 students in North Jakarta, 705 students in Central Jakarta, 290 students in East Jakarta, 71 students in South Jakarta, and 285 students in Seribu Islands. In 2013, there will be about 332.000 more to be distributed to state school and private school students. But most of this card will be distributed to private school students first, with 240.000 cards for senior high school and vocational school students, 210.000 cards for junior high school students, and 180.000 cards for elementary school students. ${ }^{25}$

This card it's very simple, straightforward, and held directly by the students. Jakarta Sehat Card is distributed evenly all, the city administration will monitor the process and its use. If it is not used in accordance with the requirements, it could be withdrawn from the students. Each card holder receives Rp. 240.000 every month to finance their school activities. It is allocated not for school

25 Berita Jakarta, December 1, 2012. Jokowi Distributed 3.013 Jakarta Smart Cards. Accessed from

http://www.beritajakarta.com/english/PrintVersion. asp?ID=25930 on August 13, 2013. fees, but to buy uniforms, shoes, books, and nutrition intakes, including transport, because school fees have been covered already.

And fifth, bureaucratic reform. After all the main issues in Jakarta resolved, I feel that the last thing he would do is to fix the bureaucratic system and clean up his government. Although, bureaucratic reform efforts must also be made in line with improvements in other sectors. Bureaucratic problems in Jakarta, including low performance from its civil servants, caused high dissatisfaction and distrust from the people. For that, I feel "blusukan" that committed by Jokowi, is one of the way to foster public confidence for his leadership in Jakarta.

Corruption is everywhere, it is endemic and it paralyzes the entire city. Personal interests are always ahead and above those of the public. In provincial government, projects related to procurement are assumed to be full of corruption. To eradicate corruption, Jokowi starts from the little things. For instance, stopping illegal charge for citizens making Jakarta Identity Card (KTP). According to Jokowi, corruption occurs due to the system and bureaucratic inefficiency. Improvements in the provincial government begin by changing several fields in the bureaucracy into online system, such as parking online, advertisement tax online, to restaurants, hotels, etc taxes are all online. Online system is a form of transparency that could prevent corruption in Jakarta.

Besides that, human resources in the provincial government should be improved and strengthened. It is because prevention and fight against corruption can only be done with a good system that is 
run by a credible human resource. This credible human resources will be empowered to conduct surveillance in all sectors, both government bureaucracy and projects carried out in the field. Last, Jokowi said that there will be a publication regarding to Jakarta Annual Local Budget (APBD). So, the people of Jakarta can now control and gain access towards public spending, and all budget related information. The publication will be delivered to all over Jakarta, without exception, as a form of transparency. Therefore, every level of society in Jakarta will have full access and knowledge about it. Public spending, procurements, and tenders will be transparent and minimize the opportunity to corrupt in local projects.

Jokowi's victory in Jakarta last year's local election was actually showing hope and confidence from the people of Jakarta to him, especially after seeing what he can do in Solo. To answer bureaucratic reform in Jakarta Provincial Government, Jokowi said that the first thing he must do is to improve his local apparatus poor performance, in terms of quality services. He wanted to do it by setting a good example and implementing tighter monitoring regulations. Doing "blusukan" is a part of his control and supervision management as a governor. An organization, without proper planning and management, as well as the absence of competent and dedicated persons inside, the result will not be good. ${ }^{26}$

Thus, whoever wants to join the carriage should then quickly adapt, or else be dismissed. He also plans to implement "one-roof" integrated services centers that will be a one-stop-shop for paying taxes,

\footnotetext{
${ }^{26}$ Joko Widodo, interview with author, August 21, 2013.
}

capital licensing for investors, and other business related issues, and plans to evaluate municipalities every six months based on public satisfaction surveys which involve local communities active participation. He added, how much time needed to work on social indentity card? Months? Weeks? Now, only days. Several of public services and licensing arrangement in districs, sub-districs, clinics, and public schools are getting faster with more service quality. Though not entirely, in the coming years every public service facilities will be made that way. ${ }^{27}$

Jokowi moves rapidly, a month after he was inaugurated, he summoned 267 neighborhood and 44 sub-district heads, giving them six months to improve bureaucratic procedures and services. The announcement came a day after Jokowi found empty offices and absent department heads during impromptu inspections of three sub-districts and one district office in Central Jakarta. The surprise inspections were part of a larger push for transparency and accountability. ${ }^{28}$ Besides that, he also reformed the administrative structures of the city council and introduced many frameworks for urban development, which he had learnt about on his visits to Europe in his previous career in business.

Jokowi's recent accomplishment in administrative service was the open recruitment process (auction) for district and sub-district heads in all over Jakarta Province. Nearly 45,000 civil servants in Jakarta just followed the open recruitment

\footnotetext{
${ }^{27}$ Joko Widodo, interview with author, August 21, 2013.

${ }^{28}$ Cogit Asia, November 15, 2012. Jokowi's Civil Servant Shake Up. Accessed from http://cogitasia.com/jokowi\%E2\%80\%99s-civilservant-shake-up/ on August 16, 2013.
} 
process. They competed for 311 positions (267 district heads and 44 sub-district heads) under a new formation of streetlevel bureaucracy. ${ }^{29}$ Jokowi's option to start open recruitment from street-level bureaucracy was a smart and strategic move. Such reform strategy will make him able to win the hearts and trust of the public quickly, directly, and tangibly.

Jokowi strives to build a new face of the country through the profile of his frontline officers who are expected to demonstrate innovation. Starting open recruitment for the lowest post of bureaucracy shows that Jokowi is giving the priority of his bureaucratic reform to public services that directly deal with the people. Selection process is intended to determine the suitability of a person's ability to post, including whether it is suitable field work or administration. ${ }^{30}$ Jakarta Governor Joko Widodo (Jokowi) confirms that the auction of office of the Government of DKI Jakarta is a form of bureaucratic reform. He said, this auction want to find leaders that has competence and quality to lead in each of their own units. $^{31}$

They are interesting fact behind why Jokowi implement this open recruitment process. Usually, not only in

29 The Jakarta Post, July 13, 2013. Reforming Street-Level Bureaucracy: Jakarta Model. Accessed from

http://www.thejakartapost.com/news/2013/07/13/re forming-street-level-bureaucracy-jakartamodel.html on August 10, 2013.

30 Sigma News, April 22, 2013. Jokowi: This Recently Was Bureaucracy Reform. Accessed from http://sigmanews.us/en/read/2183/jokowi-thisrecently-was-bureaucracyreform.htmlhttp://sigmanews.us/en/read/2183/joko wi-this-recently-was-bureaucracy-reform.html on August 16, 2013.

${ }^{31}$ Joko Widodo, interview with author, August 21, 2013.
Jakarta, but most of government level in this entire country, politicians often interrupted the bureaucracy. They have a very strong influence in the government bureaucracy. If the system doesn't allow any interruption, they will not interrupt. Politicians always interrupt the auction of village and district chief position in order to win particular candidates in their constituency sphere. For instances, in my constituency sphere, they want $\mathrm{A}$ as the village head. In the B constituency sphere, they want B as the village head, same with the district head auction. Jokowi then convinced that politician influence can be eliminated through an open selection policy of village and district head. It is an effective way to fight any interruption from politicians. Those who like to interrupt will disappear, if we reveal these interruptions to the public and mass media. Those politicians just have to go by rules, instead of using their position to persuade for their own interest.

Jokowi demonstrated that leadership is relevant and can play an important role in transforming the city into a new frontier. The real test of their leadership success will be infusing and sustaining the mind-set of civil servants. No wonder when Jokowi set the new rules of the game, these laggards suddenly find themselves incapable of adapting to the change. One of that example was when Jokowi replace the old Head of Jakarta Employment Agency (BKD) a few months ago. Jokowi stated that the replacement began when his government wanted to auction the position of local government officials, but the old BKD's Head was still indecisive. At that time, the BKD was still considering the possibility of opposition, boycott and all sorts. Jokowi then gave a 
direct order, but the old head still undecided. Finally, Jokowi put him out of office.

Jokowi assessed the opposition against the shift of position emerged because many Jakarta Provincial Government Officials felt they were already stand in their comfort zone and don't want to be replaced. That's why, it is considered as a difficult task because the removal of officials from their comfort zone to a new challenging zone can only be done with courage and decisiveness. Leadership without courage and decisiveness in Jakarta would not be heard and possess no major effect whatsoever.

Jakarta needs a new breed of leaders, who do not depend on formal authority, formal position, political and coercive power to perform their duties. Jokowi and Ahok need to substantiate their leadership with the will, commitment and capability to nurture likeminded leaders at all levels of the administration. The city is begging for a new kind of leader who has the capability and motivation to make a difference, regardless of the challenge and limitations that they face. It will require the spirit, mind, heart and body of the city to make it happen. Institutional reform is the key, otherwise the pair's efforts will be reduced to a euphoric, rhetorical game. A political game that still characterizes our country's bureaucrats, politicians and political elites.

Hopes abound that Jokowi and Ahok will strengthen the move to fight predatory political entrepreneurs. Through his participatory style of governance as the mayor of Surakarta, Jokowi has shown that leadership must be able to touch the very basis of society. He demonstrates the way in which leadership through creativity and resource-maximization may result in the diminishing "political gap" between the elites and their constituents. Thus, people feel they are part of their city and its problem solving.

Jokowi's ability to resolve the near-impossible may seem inconsequential, but this is actually a major transformational step for Indonesia. It proves that change, even in highlypoliticized Indonesia, is possible. Nonetheless, the key lesson is that change only happens when leaders engage with the people. In this respect the process, meetings, forums and discussions, are a critical part of the journey. Transformational step requires transformational leader, and Jokowi set up a good example for this country to walk from the past and face tomorrow's bright future.

\section{References}

Bangkok Post, January 8, 2013. Jokowi "Third Best Mayor in the World". Accessed from http://www.bangkokpost.com/breaki ngnews/329822/jakarta-governorthird-best-mayor-in-world on August 17, 2013.

Bass, Bernard M. 1990. From transactional to transformational leadership: Learning to share the vision. New York: Free Press.

Bisnis English, April 15, 2013. Jokowi Become too Skinny in Six Months. Accessed from http://en.bisnis.com/articles/jokowibecome-too-skinny-in-six-months on August 15, 2013.

Berita Jakarta, December 1, 2012. Jokowi

Distributed 3.013 Jakarta Smart 
Cards. Accessed from http://www.beritajakarta.com/english /PrintVersion.asp? ID $=25930$ on August 13, 2013.

Cogit Asia, November 15, 2012. Jokowi's Civil Servant Shake Up. Accessed from

http://cogitasia.com/jokowi\%E2\%80 $\% 99$ s-civil-servant-shake-up/ on August 16, 2013.

Hartiningsih, Martina. Hak Warganegara vs "Kedermawanan". Kompas, Tuesday, July 10, 2007.

Frederickson, George. Toward a New Public Administration, in Frank Marini (ed). 1971. Toward a New Public Administration. Scranton: PA. Chandler.

Hill, Linda, et all. Unlocking the Slices of Genius in Your Organization: Leading for Innovation, in Nitin Nohria and Rakesh Khurana (ed). 2010. Handbook of Leadership Theory and Practice: A Harvard Business School Centennial Colloquium. Boston: Harvard Business Press.

Jakarta Globe, January 21, 2013. SBY Approves Jokowi's Flood Prevention Programs. Accessed from http://www.thejakartaglobe.com/arch ive/sby-approves-jokowis-floodprevention-programs/ on August 09, 2013.

Maxwell, John C. 2011. The Maxwell Daily Reader. Jakarta: Bhuana Ilmu Populer.

MPR RI, January 21, 2013. Jokowi: Enam Langkah Mengatasi Banjir Jakarta. Accessed from http://www.mpr.go.id/berita/read/20 13/01/21/11541/jokowi-enam- langkah-mengatasi-banjir-jakarta on August 15, 2013.

Nugroho, Riant. 2011. Public Policy. Jakarta: Elex Media Komputindo.

Sigma News, April 22, 2013. Jokowi: This Recently Was Bureaucracy Reform. Accessed from http://sigmanews.us/en/read/2183/jo kowi-this-recently-was-bureaucracyreform.htmlhttp://sigmanews.us/en/r ead/2183/jokowi-this-recently-wasbureaucracy-reform.html on August 16, 2013.

Statistics Official Publication. Jakarta Province Poverty Level in March 2013. Statistics Central Body (BPS) Jakarta Provincial Government, no. 32/07/31/XV, July 1, 2013.

Tanuredjo, Budiman (ed). 2007. Jakarta Memilih: Pilkada dan Pembelajaran Demokrasi. Jakarta: Penerbit Buku Kompas.

Tempo English, May 28, 2013. Jokowi Distributes the New, Improved Jakarta Health Card Today. Accessed from http://en.tempo.co/read/news/2013/0 5/28/057483787/Jokowi-Distributesthe-New-Improved-Jakarta-HealthCards-Today on August 14, 2013.

The Jakarta Post, July 13, 2013. Reforming Street-Level Bureaucracy: Jakarta Model. Accessed from http://www.thejakartapost.com/news /2013/07/13/reforming-street-levelbureaucracy-jakarta-model.html on August 10, 2013.

The Jakarta Post, November 10, 2012. Jokowi Set to Launch Jakarta Health Card. Accessed from http://www.thejakartapost.com/news /2012/11/10/jokowi-set-launch- 
jakarta-health-card.html on July 30, 2013.

The World Bank. Indonesia. Accessed from

\section{Interview pictures}
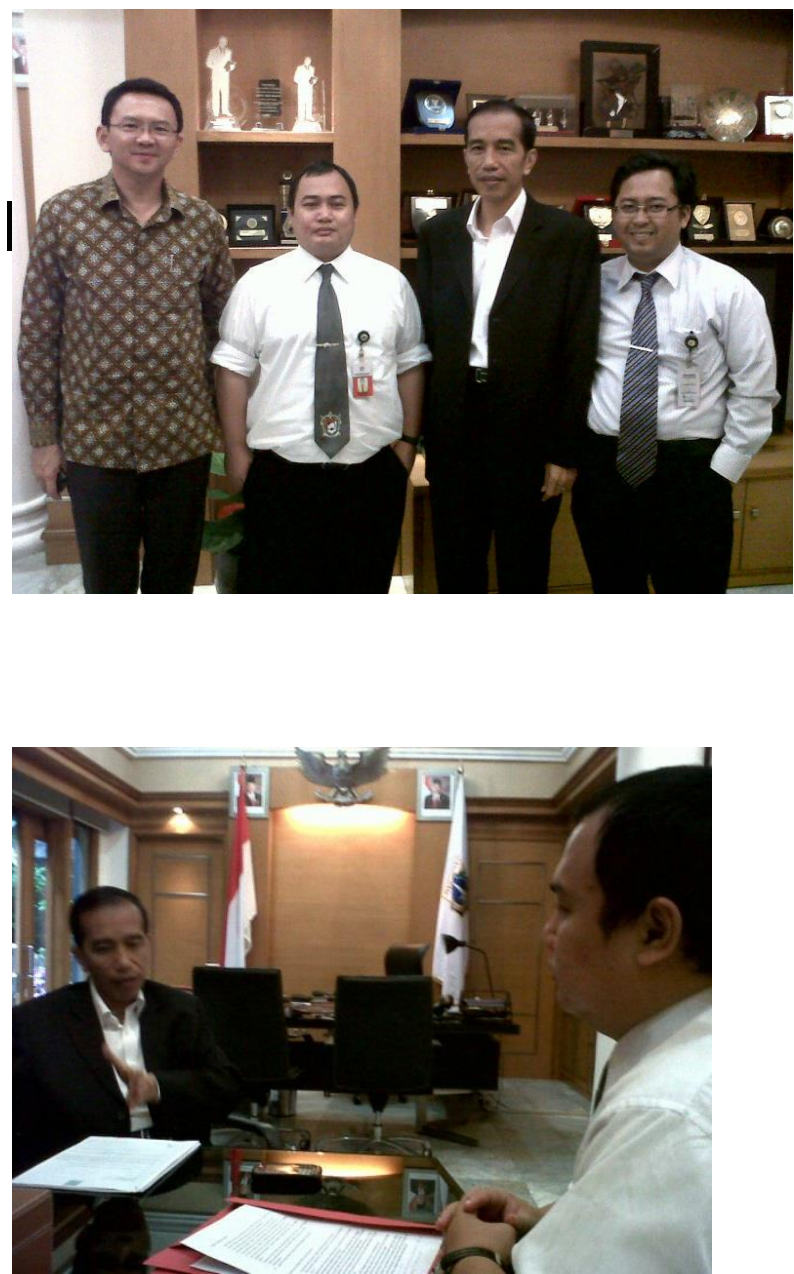

http://data.worldbank.org/country/in donesia on 16 August, 2013.

Widodo, Joko. Interview with author. August 21, 2013.

With Vice Governor Basuki Tjahaya Purnama (Ahok) in Governor's office.

From Left to Right: Ahok, Jerry, Jokowi, Rian 